\title{
Hypertension Research
}

\author{
Sorry, we don't have \\ this article in PDF format.
}

JOURNALS A-Z INDEX | WWW.NATURE.COM/HR 